$\gamma$

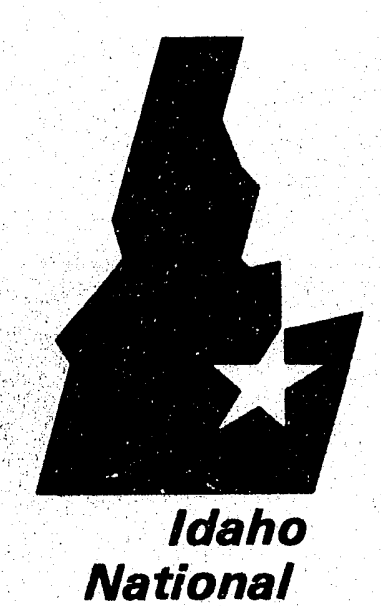

Engineering

Laboratory

\section{Managed}

by the U.S.

Department

of Energy

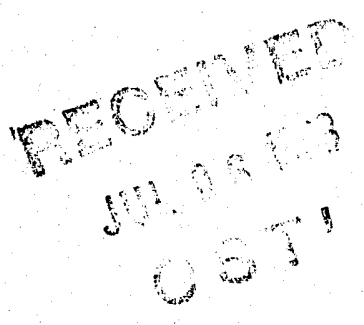

Treatability Study of Aqueous, Land Disposal Restricted Mixed Wastes

D. R. Haefner 


\title{
Treatability Study of Aqueous, Land Disposal Restricted Mixed Wastes
}

\author{
D. R. Haefner
}

Published December 1992

Idaho National Engineering Laboratory

EG\&G Idaho, Inc. Idaho Falls, Idaho 83415 


\begin{abstract}
Treatment studies have been completed on two aqueous waste streams that are classified as land disposal restricted. Both wastes had mercury and lead as characteristic hazardous constituents. Samples from one of these wastes, composed of mercury and lead sulfide particles along with dissolved mercury and lead, was successfully treated by decanting, filtering, and ion exchanging. The effluent water had an average level of 0.003 and $0.025 \mathrm{mg} / \mathrm{L}$ of mercury and lead, respectively. These values are well below the targeted RCRA limits of $0.2 \mathrm{mg} / \mathrm{L}$ mercury and $5.0 \mathrm{mg} / \mathrm{L}$ lead. An acidic stream, containing the same hazardous metals, was also successfully treated using a treatment process of precipitation, filtering, and then ion exchange. Treatment of another waste was not completely successful, presumably because of the interference of a chelating agent.
\end{abstract}

\title{
DISCLAIMER
}

\begin{abstract}
This report was prepared as an account of work sponsored by an agency of the United States Government. Neither the United States Government nor any agency thereof, nor any of their employees, makes any warranty, express or implied, or assumes any legal liability or responsibility for the accuracy, completeness, or usefulness of any information, apparatus, product, or process disclosed, or represents that its use would not infringe privately owned rights. Reference herein to any specific commercial product, process, or service by trade name, trademark, manufacturer, or otherwise does not necessarily constitute or imply its endorsement, recommendation, or favoring by the United States Government or any agency thereof. The views and opinions of authors expressed herein do not necessarily state or reflect those of the United States Government or any agency thereof.
\end{abstract}




\section{CONTENTS}

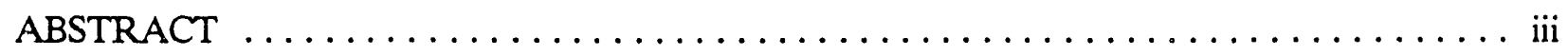

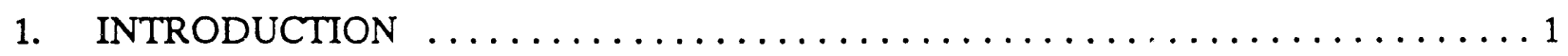

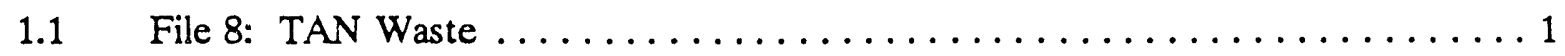

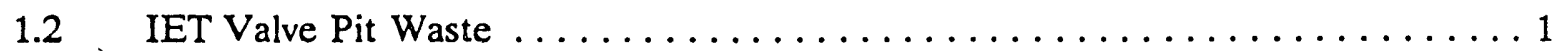

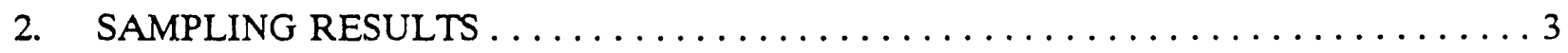

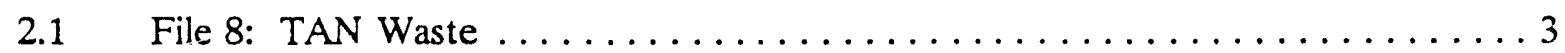

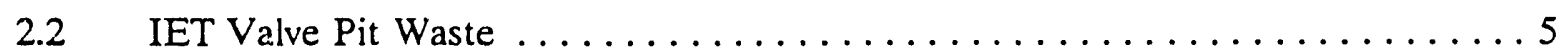

3. LABORATORY EXPERIMENTS ON SIMULATED WASTES $\ldots \ldots \ldots \ldots \ldots \ldots \ldots$

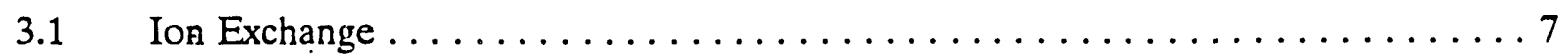

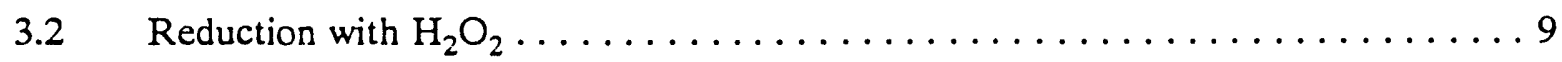

4. LABORATORY EXPERIMENTS ON ACTUAL WASTES $\ldots \ldots \ldots \ldots \ldots \ldots \ldots$

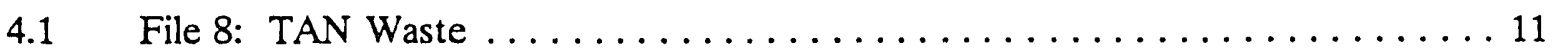

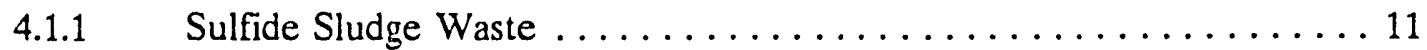

4.1.2 Acidic Waste ........................... 12

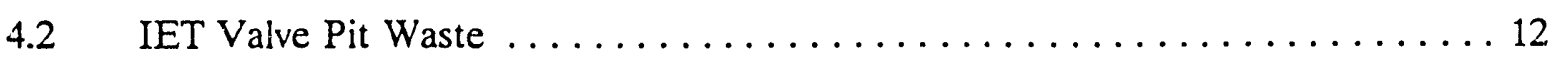

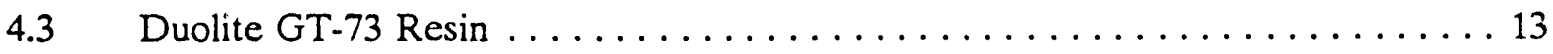

5. DISCUSSION AND RECOMMENDATIONS $\ldots \ldots \ldots \ldots \ldots \ldots \ldots \ldots \ldots \ldots$

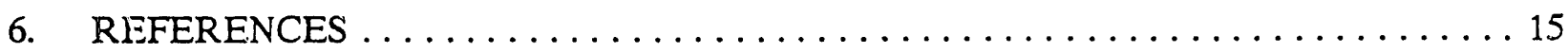

Appendix $A-G a m m a$ Analysis $\ldots \ldots \ldots \ldots \ldots \ldots \ldots \ldots \ldots \ldots \ldots \ldots \ldots \ldots \ldots \ldots \ldots \ldots \ldots$

\section{FIGURE}

1. Breakthrough curves for mercury and lead on GT-73 resin $\ldots \ldots \ldots \ldots \ldots \ldots$ 


\section{TABLES}

1. Toxic metals content in the liquid phase of File $8:$ TAN waste $\ldots \ldots \ldots \ldots \ldots$

2. Toxic metals content in the filtered solids of File 8 : TAN waste $\ldots \ldots \ldots \ldots \ldots$

3. Gross alpha/beta analysis of the File 8 : TAN waste $\ldots \ldots \ldots \ldots \ldots \ldots \ldots \ldots$

4. Toxic metals content in the liquid phase of the IET valve pit waste $\ldots \ldots \ldots \ldots \ldots$

5. Toxic metals content in the filtered solids of the IET valve pit waste $\ldots \ldots \ldots \ldots$

6. Gross alpha/beta analysis of the IET valve pit waste $\ldots \ldots \ldots \ldots \ldots \ldots \ldots$

7. Operating parameters of the ion exchange experiment $\ldots \ldots \ldots \ldots \ldots \ldots \ldots$

8. Operating parameters for the treatment of File 8 sludge waste $\ldots \ldots \ldots \ldots \ldots \ldots$ 


\section{Treatability Study of Aqueous, Land Disposal Restricted Mixed Waste}

\section{INTRODUCTION}

The Mixed Waste Storage Facility (MWSF) contains several liquid streams that are classified as Land Disposal Restricted (LDR). These wastes contain characteristic hazardous constituents in addition to radioactive material. The primary objective of the work described in this report is to specify a treatment for two of the LDR wastes and thereby render them suitable for permanent disposal.

The wastes targeted in this study contain lead and mercury above their respective RCRA limits of 5.0 and $0.2 \mathrm{mg} / \mathrm{L}$. The goal of the treatment is to have the liquid effluents meet these limits and also to retain the toxic metals in a stable, nonleachable solid form. This would reduce the original LDR stream to two low-level waste streams suitable for disposal.

The targeted streams were identified from waste manifests and shipping records. Initially, ion exchange was considered as the sole treatment necessary; however, largely from a sampling program, and to a lesser extent through conversations with generators, it was determined that precipitation and/or filtering was required before polishing by ion exchange.

The historical aspects of the two wastes are discussed below. The analytical results of drum sampling are given in Section 2.

\subsection{File 8: TAN Waste}

The waste identified as "File 8: TAN Waste" comprises 33 drums of rinse water originating from the washing of a cooling jacket contaminated with elemental mercury. A $30 \%$ nitric acid rinse solution was circulated through the jacket to dissolve the mercury. Caustic was then added to bring the $\mathrm{pH}$ up to the 10 to 12 range and caused the mercury to precipitate as the hydroxide. The final step was the addition of sodium sulfide to convert the mercury to the highly stable, sulfide form.

Shipping manifests indicate that twenty-nine of the 33 drums are believed to have been processed as described above. The four other drums were originally labelled as corrosive and would therefore have a $\mathrm{pH}$ of less than 2. One of these four was later relabelled and was not shipped as a corrosive solution.

Six of the 33 drums were sampled: four of the suspected alkaline, one of the acidic drums, and the drum with the altered designation were chosen. The complete results of the lab analysis are presented and discussed in Section 2.

\subsection{IET Valve Pit Waste}

This stream consists of two drums of water that had accumulated in the Initial Engine Test (IET) valve pit at TAN. The exact source of this water is unknown, but was presumably from storm 
drain overflows. The treatment of this water prior to drumming and shipment to the MWSF is also unclear. Shipping records include an extensive metals analysis, which indicates that the waste is heavily loaded with dissolved metals, but that only mercury and lead are above the RCRA limit. The analysis also indicates the suspected presence of surfactants, chelating agents, and/or heavy organic material. 


\section{SAMPLING RESULTS}

\subsection{File 8: TAN Waste}

As mentioned above, 6 of the 33 "File 8: TAN Waste" drums were sampled. Four of these had pHs near 10 , another had a $\mathrm{pH}$ of 7 , while the last was about 2 . All samples contained a dark brown sediment, although the acidic sample had only trace amounts. The liquid phase varied from yellow to light brown for the alkaline samples, while the acidic waste was nearly clear.

Metals analyses, as determined by Inductively Coupled Plasma Emission Spectroscopy (ICP), are given in Tables 1 and 2. Table 1 shows that in addition to mercury, lead is above the regulatory limit for two of the samples. Although not mentioned in the shipping records, it is commonly used onsite and may have been used within the cooling jacket equipment.

Table 2 details information on the particulates in the File 8 waste. Most solids are retained on the $0.45 \mu \mathrm{m}$ filter, but leakage of very fine particles was found on the finer 0.1 filter. Although seemingly small, the amount of mercury and lead passing through the $0.45 \mu \mathrm{m}$ filter would be enough to exceed the allowable limits for several of the samples. For example, drum 568 leakage would roughly calculate to $520 \mathrm{ppm}$ mercury, well in excess of the 0.2 limit.

In addition to the metals analysis, the samples were also analyzed for gross alpha/beta, which appear in Table 3, and isotopic gamma, given in Appendix A. Most of the radioactivity resides in the sludge, as shown by Table 3 , while the water is relatively nuclide free. 
Table 1. Toxic metals content in the liquid phase of File 8: TAN waste. ${ }^{2}$

\begin{tabular}{ccccc}
\hline $\begin{array}{c}\text { Drum } \\
\text { number }\end{array}$ & $\begin{array}{c}\text { Total } \\
\text { dissolved } \\
\text { solids } \\
(\mathrm{mg} / \mathrm{mL})\end{array}$ & $\begin{array}{c}\text { Chromium } \\
(\mathrm{ppm})\end{array}$ & $\begin{array}{c}\text { Mercury } \\
(\mathrm{ppm})\end{array}$ & $\begin{array}{c}\text { Lead } \\
(\mathrm{ppm})\end{array}$ \\
\hline 568 & 223.4 & 0.001 & 0.326 & 0.622 \\
572 & 16.6 & 0.020 & 0.133 & 0.674 \\
635 & 3.9 & 0.015 & 4.68 & 2.88 \\
697 & 264.4 & 0.006 & 0.340 & 8.10 \\
703 & 89.6 & 0.057 & 0.301 & 2.87 \\
702 & 3.2 & 1.789 & $20,000^{\mathrm{a}}$ & $1,120^{\mathrm{a}}$ \\
& & & \\
\hline
\end{tabular}

Table 2. Toxic metals content in the filtered solids of File 8: TAN waste. ${ }^{2}$

\begin{tabular}{ccccccc}
\hline \multirow{2}{*}{$\begin{array}{c}\text { Drum } \\
\text { number }\end{array}$} & \multicolumn{2}{c}{ Filterable solids: } & & $\begin{array}{c}\text { Chromium } \\
(\mu \mathrm{g} \mathrm{Cr} / \mathrm{mg} \\
\text { solid })\end{array}$ & $\begin{array}{c}\text { Mercury } \\
(\mu \mathrm{g} \mathrm{Hg} / \mathrm{mg} \\
\text { solid })\end{array}$ & $\begin{array}{c}\text { Lead } \\
(\mu \mathrm{mg} / \mathrm{mL}) \\
\text { solid })\end{array}$ \\
\hline 568 & 953.6 & $\begin{array}{c}0.1 \mu \mathrm{mg}-0.45 \mu \mathrm{m} \\
(\mathrm{mg} / \mathrm{mL})\end{array}$ & 9.7 & 0.787 & 54.5 & 101.3 \\
572 & 612.5 & 0.1 & 0.261 & 2.98 & 189.4 \\
635 & 782.1 & 0.0 & 0.659 & 9.37 & 651.4 \\
697 & 277.3 & 2.6 & 1.420 & 138.0 & 135.0 \\
703 & 419.6 & 2.2 & 0.567 & 46.9 & 154.0 \\
702 & 4.0 & 0.2 & 2.21 & 80.0 & 66.9 \\
\hline
\end{tabular}


Table 3. Gross alpha/beta analysis of the File 8: TAN waste. ${ }^{2}$

\begin{tabular}{ccccc}
\hline $\begin{array}{c}\text { Drum } \\
\text { number }\end{array}$ & $\begin{array}{c}\text { Liquid } \\
\text { gross } \alpha \\
(\mathrm{pCi} / \mathrm{mL})\end{array}$ & $\begin{array}{c}\text { Liquid } \\
\text { gross } \beta \\
(\mathrm{pCi} / \mathrm{mL})\end{array}$ & $\begin{array}{c}\text { Solid } \\
\text { gross } \alpha \\
(\mathrm{pCi} / \mathrm{g})\end{array}$ & $\begin{array}{c}\text { Solid } \\
\text { Gross } \beta \\
(\mathrm{pCi} / \mathrm{g})\end{array}$ \\
\hline 568 & $2.4 \times 10^{-1}$ & 74.0 & $3.6 \times 10^{1}$ & $2.0 \times 10^{4}$ \\
572 & $2.8 \times 10^{-2}$ & 0.65 & $8.0 \times 10^{1}$ & $1.0 \times 10^{3}$ \\
635 & $1.0 \times 10^{-1}$ & 2.2 & - & $4.9 \times 10^{3}$ \\
697 & $0.6 \times 10^{-1}$ & 3.7 & - & $4.0 \times 10^{4}$ \\
703 & $2.3 \times 10^{-1}$ & 2.7 & - & $7.1 \times 10^{3}$ \\
702 & $4.2 \times 10^{-1}$ & 44.0 & $3.6 \times 10^{3}$ & $1.0 \times 10^{4}$ \\
Note: A dash (-) represents a value below the detection limit, & Radiochemistry Analytical \\
Procedure (RAP)-2. & & & \\
\hline
\end{tabular}

\subsection{IET Valve Pit Waste}

Both of the drums comprising this waste stream were sampled. The liquid portion was yellowbrown and very viscous with a gel-like character. The sediment was cream to gray in color and was believed to be gravel and sand. There was also small debris such as insect parts in the waste. Both samples had $\mathrm{pH}$ values near 10.

Lab analysis of these samples is shown in Tables 4-6, while Appendix A provides results from an isotopic gamma analysis. Tables 4 and 5 show most of the metals remain in solution, even though the $\mathrm{pH}$ is alkaline; these data suggest the presence of a chelating agent. 
Table 4. Toxic metals content in the liquid phase of the IET valve pit waste. ${ }^{2}$

\begin{tabular}{ccccc}
\hline $\begin{array}{c}\text { Drum } \\
\text { number }\end{array}$ & $\begin{array}{c}\text { Total } \\
\text { dissolved } \\
\text { solids } \\
(\mathrm{mg} / \mathrm{mL})\end{array}$ & $\begin{array}{c}\text { Chromium } \\
(\mathrm{ppm})\end{array}$ & $\begin{array}{c}\text { Mercury } \\
(\mathrm{ppm})\end{array}$ & $\begin{array}{c}\text { Lead } \\
(\mathrm{ppm})\end{array}$ \\
\hline $676 \mathrm{~A}$ & 34.3 & 3.357 & 1.50 & 16.77 \\
$677 \mathrm{~A}$ & 35.3 & 3.449 & 0.795 & 17.69 \\
\hline
\end{tabular}

Table 5. Toxic metals content in the filtered solids of the IET valve pit waste. ${ }^{2}$

\begin{tabular}{cccccc}
\hline \multirow{2}{*}{$\begin{array}{c}\text { Drum } \\
\text { number }\end{array}$} & $\begin{array}{c}20.45 \mu \mathrm{m} \\
(\mathrm{mg} / \mathrm{mL})\end{array}$ & $\begin{array}{c}0.1 \mu \mathrm{m}-0.45 \mu \mathrm{m} \\
(\mathrm{mg} / \mathrm{mL})\end{array}$ & $\begin{array}{c}\text { Chromium } \\
(\mu \mathrm{g} \mathrm{Cr} / \mathrm{mg} \\
\text { solid })\end{array}$ & $\begin{array}{c}\text { Mercury } \\
(\mu \mathrm{g} \mathrm{Hg} / \mathrm{mg} \\
\text { solid })\end{array}$ & $\begin{array}{c}\text { Lead } \\
(\mu \mathrm{g} \mathrm{Pb} / \mathrm{mg} \\
\text { solid })\end{array}$ \\
\hline $676 \mathrm{~A}$ & 311.8 & 0.8 & 0.234 & 0.85 & 0.947 \\
$677 \mathrm{~A}$ & 84.4 & 1.3 & 0.17 & $<0.01$ & 1.6 \\
\hline
\end{tabular}

Table 6. Gross alpha/beta analysis of the IET valve pit waste. ${ }^{2}$

\begin{tabular}{ccccc}
\hline $\begin{array}{c}\text { Drum } \\
\text { number }\end{array}$ & $\begin{array}{c}\text { Liquid } \\
\text { gross } \alpha \\
(\mathrm{pCi} / \mathrm{m} \\
\mathrm{L})\end{array}$ & $\begin{array}{c}\text { Liquid } \\
\text { gross } \beta \\
(\mathrm{pCi} / \mathrm{mL}\end{array}$ & $\begin{array}{c}\text { Solid } \\
\text { gross } \alpha \\
(\mathrm{pCi} / \mathrm{g})\end{array}$ & $\begin{array}{c}\text { Solid } \\
\text { gross } \beta \\
(\mathrm{pCi} / \mathrm{g})\end{array}$ \\
\hline $676 \mathrm{~A}$ & 4.1 & $1.8 \times 10^{3}$ & $1.4 \times 10^{3}$ & $1.5 \times 10^{6}$ \\
$677 \mathrm{~A}$ & 3.5 & $1.7 \times 10^{3}$ & - & $1.0 \times 10^{6}$
\end{tabular}

Note: A dash ( $\cdots)$ represents a value below the detection limit, Radiochemistry Analytical Procedure (RAP)-2. 


\section{LABORATORY EXPERIMENTS ON SIMULATED WASTES}

The laboratory work was divided into two parts: cold tests using simulated waste and hot tests using actual samples. The primary emphasis of the cold tests was to evaluate the ion exchange resin for removal of lead and mercury. Another lab test in the cold studies included a scheme to reduce mercury sulfide to elemental mercury by hydrogen peroxide.

\subsection{Ion Exchange}

Duolite GT-73 ion exchange resin was tested in a column configuration. A solution with known mercury and lead content was fed to the column until the bed became nearly saturated, at which point the level of metals in the effluent rose and followed the typical breakthrough pattern. The information derived from this breakthrough curve included the effective loading capacity of the resin as well as its polishing capability.

The resin was tested in a glass column, $1.5 \mathrm{~cm} \mathrm{ID,} \mathrm{equipped} \mathrm{with} \mathrm{chemical} \mathrm{resistant}$ polypropylene and teflon components. A variable speed/reversible peristaltic pump with thick walled tygon tubing was used to pump the feed solution. A 1 to 3 in. liquid level was maintained above the resin to ensure good distribution of fluid across the bed's cross section and to supply the hydrostatic pressure to force the solution through the resin. Downstream of the column, the liquid flow was monitored and controlled with a rotameter and precision stainless steel needle valve. Effluent samples were withdrawn through a short sampling line immediately below the column exit. These were later analyzed for metals by ICP.

Table 7 presents the operating conditions for the ion exchange experiment. The feed was prepared by diluting a mercury and lead stock solution. Seven liters of solution $\left(128.5 \mathrm{ppm} \mathrm{Hg}^{++}\right.$ and $6.7 \mathrm{ppm}^{\mathrm{Pb}^{++}}$) were initially prepared and sent through the column. Later analysis of the effluent revealed that breakthrough had not occurred. Feed solutions thereafter were prepared in one liter increments to avoid generating excess waste. The corresponding feed concentrations are shown in Figure 1. 


\section{Average Resin Capacity - g Hg, $\mathrm{Pb} /$ liter resin}

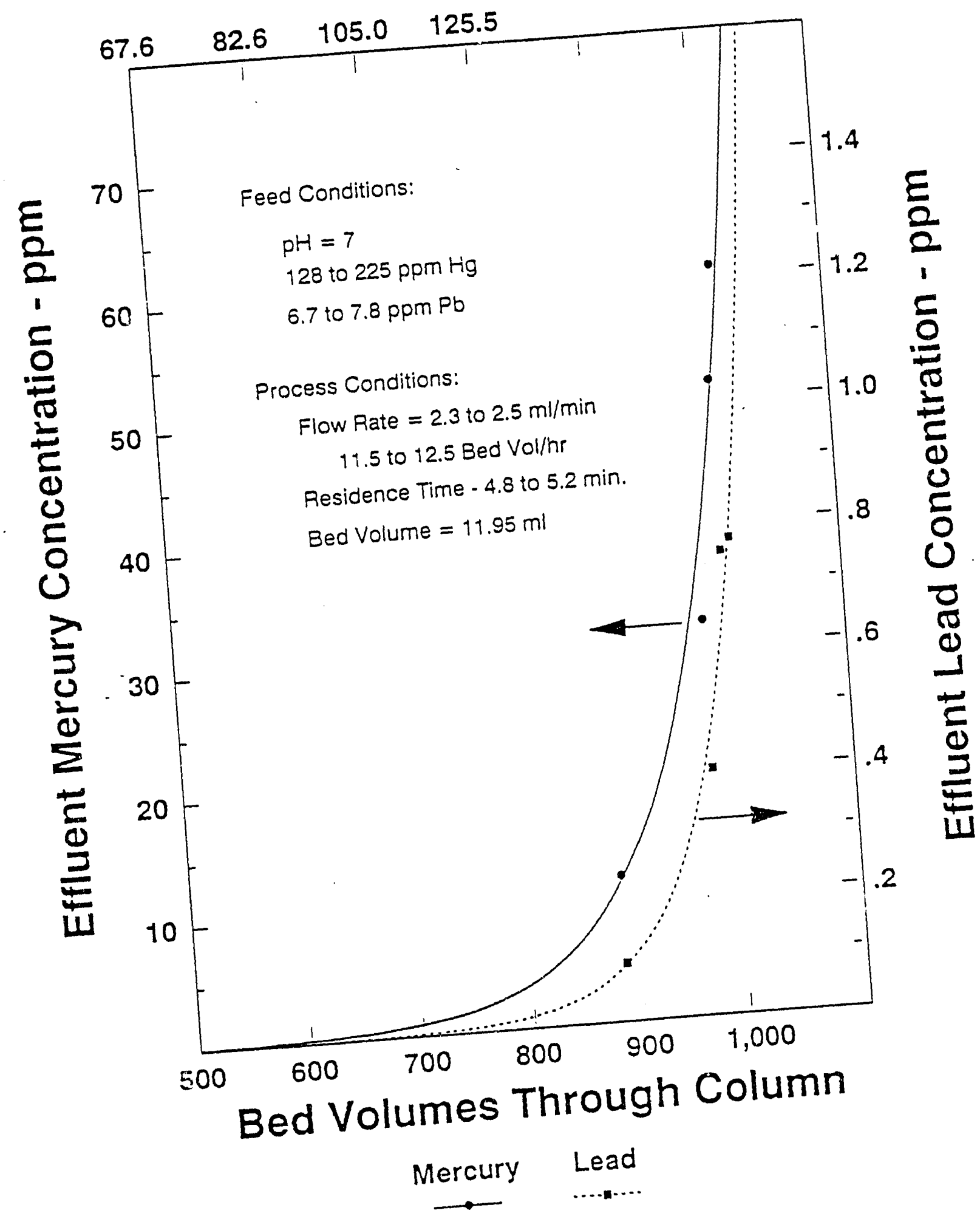

Figure 1. Breakthrough curves for mercury and lead on GT-73 resin. 
Table 7. Operating parameters of the ion exchange experiment.

\begin{tabular}{ll} 
Feed solution: & \\
\hline $\mathrm{pH}$ & 7 \\
Mercury & 128.5 to $225 \mathrm{ppm} \mathrm{Hg}^{++}$ \\
Lead & 6.7 to $7.8 \mathrm{ppm} \mathrm{Pb}{ }^{++}$ \\
Flow rate & 2.3 to $2.5 \mathrm{~mL} / \mathrm{min}$ \\
& 11.5 to $12.5 \mathrm{bed} \mathrm{vol} / \mathrm{hr}$ \\
Bed characteristics: & \\
\hline Resin & Duolite GT-73 \\
Bed height & $6.75 \mathrm{~cm}$ \\
Bed volume & $11.95 \mathrm{~mL}$ \\
\hline
\end{tabular}

The experimental breakthrough curve, shown in Figure 1, has the typical breakthrough shape: a concentration profile, which is very flat at the beginning, and then steadily rises as the bed becomes saturated. The steep portion of the curve was used to estimate, by interpolation, the effective resin loading capacity as about $130 \mathrm{~g} \mathrm{Hg}^{++} \mathrm{Pb}^{++}$per liter of resin bed.

The feed to the bed was very high in mercury, ranging from 128 to $225 \mathrm{ppm}$. At these levels, the resin manufacturer recommends a two-stage system: the first column to remove the bulk of the mercury, and the second used as a polishing column. However, only a single column was used in this experiment and in spite of this limitation, the mercury level in the effluent was consistently near or below the RCRA limit of $0.2 \mathrm{ppm}$. Lead was easily removed to below the $5 \mathrm{ppm} \mathrm{RCRA} \mathrm{limit} \mathrm{with}$ a feed ranging from 6.7 to $7.8 \mathrm{ppm}^{\mathrm{a}}$

\subsection{Reduction with $\mathrm{H}_{2} \mathrm{O}_{2}$}

Most of the mercury in the waste is in the form of mercuric sulfide. One scheme under consideration was to chemically treat the mercuric sulfide and reduce it to the elemental state. The mercury could then be removed by decanting. This concept involved oxidizing the mercuric sulfide to sulfate, which in turn would decompose to elemental mercury and a sulfate salt if a less noble metal, such as copper, were present.

Several tests were run using different combinations of reagents; only marginal success was achieved. In the successful tests, mercury sulfide sludge was added directly to a $30 \% \mathrm{H}_{2} \mathrm{O}_{2}$ solution to which a thin winding of copper was also added. A very vigorous reaction ensued with bubbling

a. Laboratory notebook, "No. INEL-NBU-2874," assigned to B. Mincher and D. Haefner. 
and the evolution of much heat. In one case, small brown spheres formed at the bottom of the beaker. These were believed to be mercury/copper amalgams. In the other case, small silver beads of mercury were formed. Duplication of these experiments was unsuccessful.

Further work with the chemical treatment was abandoned for several reasons. Understanding and controlling the chemistry to obtain a consistent product would have required extensive work beyond the time frame aiiowed by the project. Secondly, the mercuric sulfide had to be placed in a concentrated solution of peroxide to become reduced. In the actual waste, the suifide is dispersed throughout an aqueous phase. Obtaining adequate contact between the sulfide and peroxide would have been doubtful. 


\section{LABORATORY EXPERIMENTS ON ACTUAL WASTES}

\subsection{File 8: TAN Waste}

As described in Section 2.1, this waste is not a single homogeneous stream, but more closely resembles two distinct wastes. One portion is composed primarily of metal sulfide sludge in water with low levels of dissolved mercury and lead, while the other contains acidic liquid with most of the metals dissolved in solution.

\subsubsection{Sulfide Sludge Waste}

There were 10 samples sent to the lab that contained the sulfide sludge. Over the course of several weeks, most of the particles had settled; there was very little suspended matter. The liquid from two of these containers (drums 572 and 635) was decanted, combined, and passed through a 0.45 micron filter. Very little material was retained by the filter, while the filtrate was clear with only a slight yellow discoloration. This solution was then run through the ion exchange column.

The remaining 8 containers were decanted, filtered through a 0.45 micron membrane, and combined into a single stream. After sitting for a few days, there were obvious precipitates present in the stream. This solution was filtered with a 0.45 micron membrane and then passed through the ion exchange column. The feed solution was a pale lemon color, while the effluent retained only a slight yellow discoloration. Table 8 presents the operating conditions for the ion exchange column.

Table 8. Operating parameters for the treatment of File 8 sludge waste.

\begin{tabular}{ll} 
Feed solution: & Filtered File 8 sludge \\
\hline $\mathrm{pH}$ & $10-11$ \\
Mercury & $1.2 \mathrm{Hg}^{++}$approximately \\
Lead & $3.0 \mathrm{~Pb}^{++}$approximately \\
Flow rate & 4.0 to $5.9 \mathrm{~mL} / \mathrm{min}$ \\
& 11.5 to $12.5 \mathrm{bed} \mathrm{vol} / \mathrm{hr}$ \\
Bed characteristics: & \\
\hline Resin & Duolite GT-73 \\
Bed height & $19.5 \mathrm{~cm}$ \\
Bed volume & $34.5 \mathrm{~mL}$
\end{tabular}


Two samples were drawn from the effluent container and sent to the contract lab. The analytical results show that both mercury and lead were reduced to well below their RCRA limits. The average levels were $0.003 \mathrm{ppm}$ for mercury and 0.025 for lead. ${ }^{\mathrm{b}}$

The solids/sludge portion of the wastes were combined into a single container and a sample drawn and sent for TCLP testing. This sample passed the leaching procedure for mercury, but failed for lead. ${ }^{c}$

The balance of the sludge was solidified using a Portland type cement. The resultant concrete was also subjected to TCLP tests and was found to retain the metals in a non-leachable product. The cement recipe and TCLP results can be found in EGG-WM-10533. ${ }^{3}$

\subsubsection{Acidic Waste}

The acidic File 8 waste was handled differently than the sludge. The $\mathrm{pH}$ of the waste was about 2 and essentially all the heavy metals were dissolved in solution. The initial treatment was adding caustic $(50 \% \mathrm{NaOH})$ until the $\mathrm{pH}$ was about 10 to cause precipitation of the metals. The solution was then allowed to sit overnight to settle the solids.

Unlike sulfide precipitation, the mercury and lead hydroxides readily settle to give a clear liquid phase. This liquid was decanted, filtered through a $0.45 \mu \mathrm{m}$ membrane, and then sampled and analyzed for lead and mercury. A relatively large amount of these metals remained dissolved in the solution. An ICP analysis determined the levels to be about $166 \mathrm{ppm}$ mercury and $94 \mathrm{ppm}$ lead. Because of high metals loading, this solution was run through the ion exchange column twice.

An effluent sample was drawn and sent to the contract lab. Results show mercury reduced to $0.143 \mathrm{ppm}$ and lead to $0.076 \mathrm{ppm}$ (see footnote a).

\subsection{IET Valve Pit Waste}

About 2.5 liters of this waste was sampled and sent to the lab. Because of suspected presence of a chelating agent, initial tests were undertaken to break the chelated complex. Ethylenediamine tetraacetic acid (EDTA) is a commonly used chelating agent and can be broken and removed from solution, as a precipitated solid, by dropping the $\mathrm{pH}$ to about 3 .

Concentrated nitric acid was added to about $30 \mathrm{~mL}$ of the IET waste to adjust the $\mathrm{pH}$ from 10 to 2 . The solution bubbled vigorously as acid was added. Accompanying the $\mathrm{pH}$ change was also the evolution of some heat as well as a color change from dull brownish yellow to bright yellow; no precipitation was apparent. The solution was allowed to sit for about 48 hours and still no precipitates formed.

b. Data package from TCT-St. Louis, EG\&G subcontract: TOS No. ERD-TOS-02, MOD1, September 29, 1992.

c. Data package from TCT-St. Louis, EG\&G subcontract: TOS No. ERD-TOS-02, MOD2. December 2, 1992. 
Because the above test was nondefinitive, another set of six tests were performed. To the untreated "raw" waste, hydroxide and sulfide additions caused no precipitates to form. This indicates the presence of an active chelate. To the acidified waste, hydroxide addition was negative, but sulfide caused the precipitation of a white compound. This result was interpreted as follows: the chelate was deactivated in the acid, but hydroxide addition was negative because the acid media kept the hydroxide compounds dissolved. Sulfide compounds are much more insoluble, even under acidic conditions, and therefore the sulfide addition resulted in a positive precipitate formation. For the last tests, the acidified liquid was adjusted to an alkaline $\mathrm{pH}$ and again hydroxide and sulfide were added. No precipitates formed and it was thereby reasoned that the chelate was reactivated in the basic media.

Concentrated nitric acid was added to the balance of the IET waste until the $\mathrm{pH}$ was about 2 . The solution was then decanted from the grit and debris and filtered through a 0.45 membrane. Eveil though no solids were picked up on the membrane, filtering was very slow because of the gelatin-like character of the waste. A larger pore filter was thereafter used to hasten the filtering. The clear solution was then twice passed through the ion exchange column.

The effluent was sampled and sent to the contract lab for TCLP metals and pesticides/herbicides organics analyses. No regulated organics were found. Mercury was successfully removed down to $.00077 \mathrm{ppm}$, however lead remained after treatment with a concentration of $22.3 \mathrm{ppm}$ (see footnote $b$ ).

\subsection{Duolite GT-73 Resin}

The resin used throughout these experiments was combined and sent to the contract lab for TCLP metals analysis. The resin successfully passed the leaching test and can therefore be disposed of as a low-level waste (see footnote b). 


\section{DISCUSSION AND RECOMMENDATIONS}

The laboratory tests positively demonstrated that mercury and lead could be removed to below RCRA limits for the File 8 waste. The essential features of the treatment for the sulfide sludge portion were as follows:

1. Allow the metal sulfides to settle; this may require several hours

2. Decant the water layer and pass through a $0.45 \mu \mathrm{m}$ filter

3. Run the water through the resin at about 10 bed volumes/hour.

It was observed that combining samples from different drums could result in the formation of precipitates. This may have resulted from sight variations in $\mathrm{pH}$ between the samples or possibly differences in the chemical constituents. For example, it is noted that two of the samples had extremely high aluminum levels of 240 and $520 \mathrm{ppm}$. Under proper conditions, aluminum can form several different insoiuble complexes. If any insoluble material enters the resin column, there is a risk of fouling the resin and thereby preventing any ion exchange from taking place. Resin fouling was not a problem in the lab processing because the waste was ion exchanged immediately after filtering.

The processing of the acidic portion of the File 8 waste was straight forward and also proved to be an effective treatment. The essential process features were as follows:

1. Add caustic $(50 \%)$ to a $\mathrm{pH}$ of about 10

2. Allow the precipitated metals to settle, this should proceed fairly quickly to give a very clear liquid phase

3. Decant the water and pass through a $0.45 \mu \mathrm{m}$ filter

4. Run a two-pass ion exchange process with each pass at about 10 bed volumes/hour.

No anomalies were noticed in the treatment of this waste.

The treatment scheme outlined for the IET Valve Pit waste was unsuccessful. Mercury was apparently freed from the chelating agent, but lead was not. The recommended treatment for this waste is solidification. 


\section{REFERENCES}

1. Letter from R. P. Wells to D. R. Haefner, EG\&G Idaho, "Ion Exchange Studies for WERF Waste," No. RWP-10-92, available from Wells letter file, March 18, 1992.

2. Letter from T. J. Haney to D. R Haefner, EG\&G Idaho, "Gamma-ray Analyses of Eight Waste Water Samples from the Mixed Waste Storage Facility," No. TJH-21-92, available from Haney letter file, March 10, 1992.

3. K. Gerhig, Treatability Study for the Bench-Scale Solidification on Nonincinerable LDR LowLevel Mixed Waste, EGG-WM-10533, December 1992. 
Appendix A

Gamma Analysis 


\section{Appendix A}

\section{Gamma Analysis}

Table A-1. Gamma Analysis of the File 8: TAN Waste.

Activity

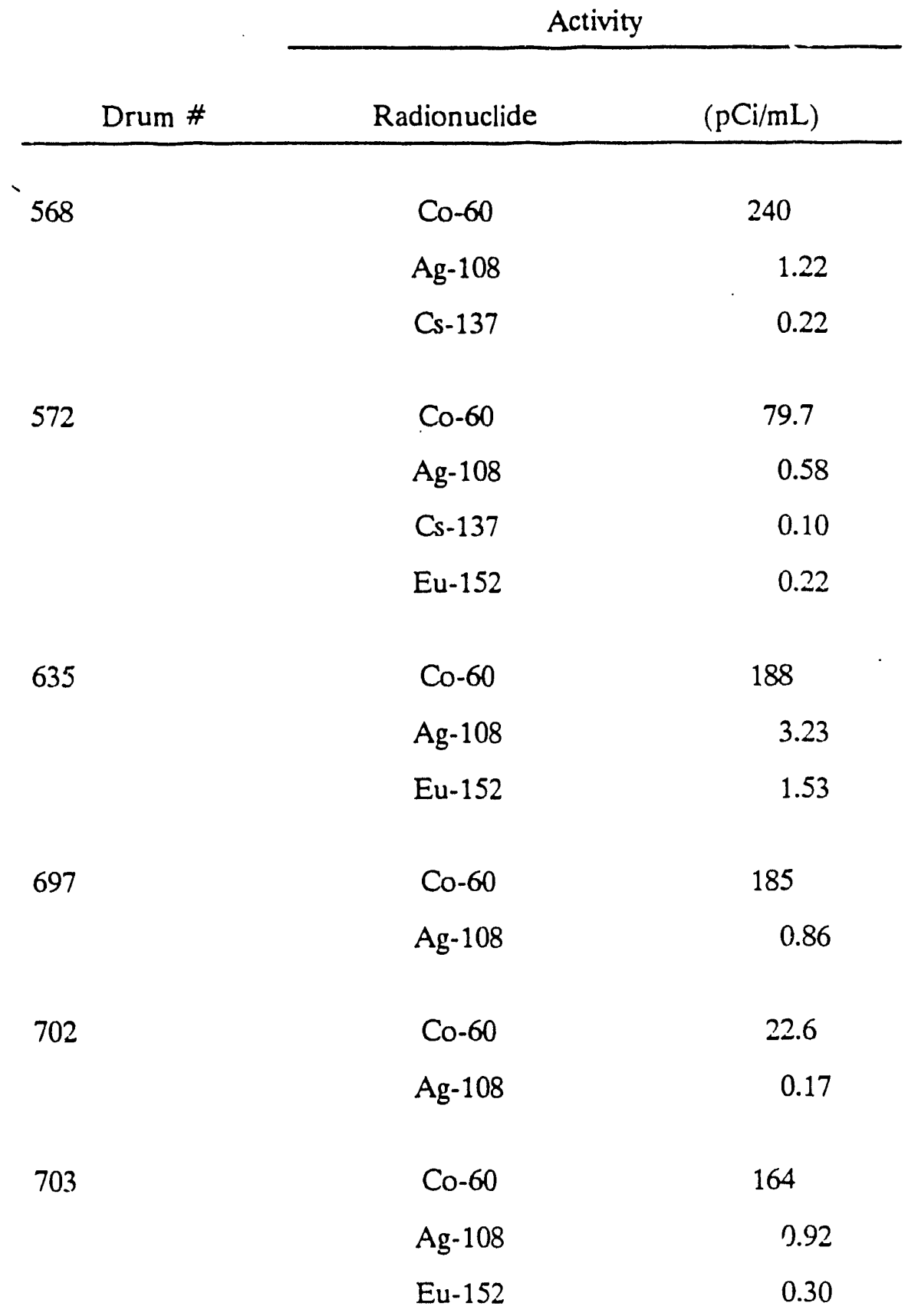

* Samples counted for 16 hours. 
Table A-2. Gamma Analysis of the IET Valve Pit Waste.

Activity

\begin{tabular}{|c|c|c|}
\hline Drum \# & Radionuclide & $(\mathrm{pCi} / \mathrm{mL})$ \\
\hline \multirow[t]{7}{*}{$676 \mathrm{~A}$} & Co- 60 & 213 \\
\hline & $\mathrm{Nb}-94$ & 0.36 \\
\hline & Cs-134 & 1.45 \\
\hline & Cs-137 & 4610 \\
\hline & Eu-152 & 2.40 \\
\hline & Eu-154 & 8.01 \\
\hline & Eu-155 & 3.22 \\
\hline \multirow[t]{7}{*}{$677 \mathrm{~A}$} & Co- 60 & 29.6 \\
\hline & $\mathrm{Nb}-94$ & 0.19 \\
\hline & Cs-134 & 0.24 \\
\hline & Cs-137 & 643 \\
\hline & Eu-152 & 1.45 \\
\hline & Eu-154 & 4.64 \\
\hline & Eu-155 & 1.04 \\
\hline
\end{tabular}

* Samples counted for 16 hours. 

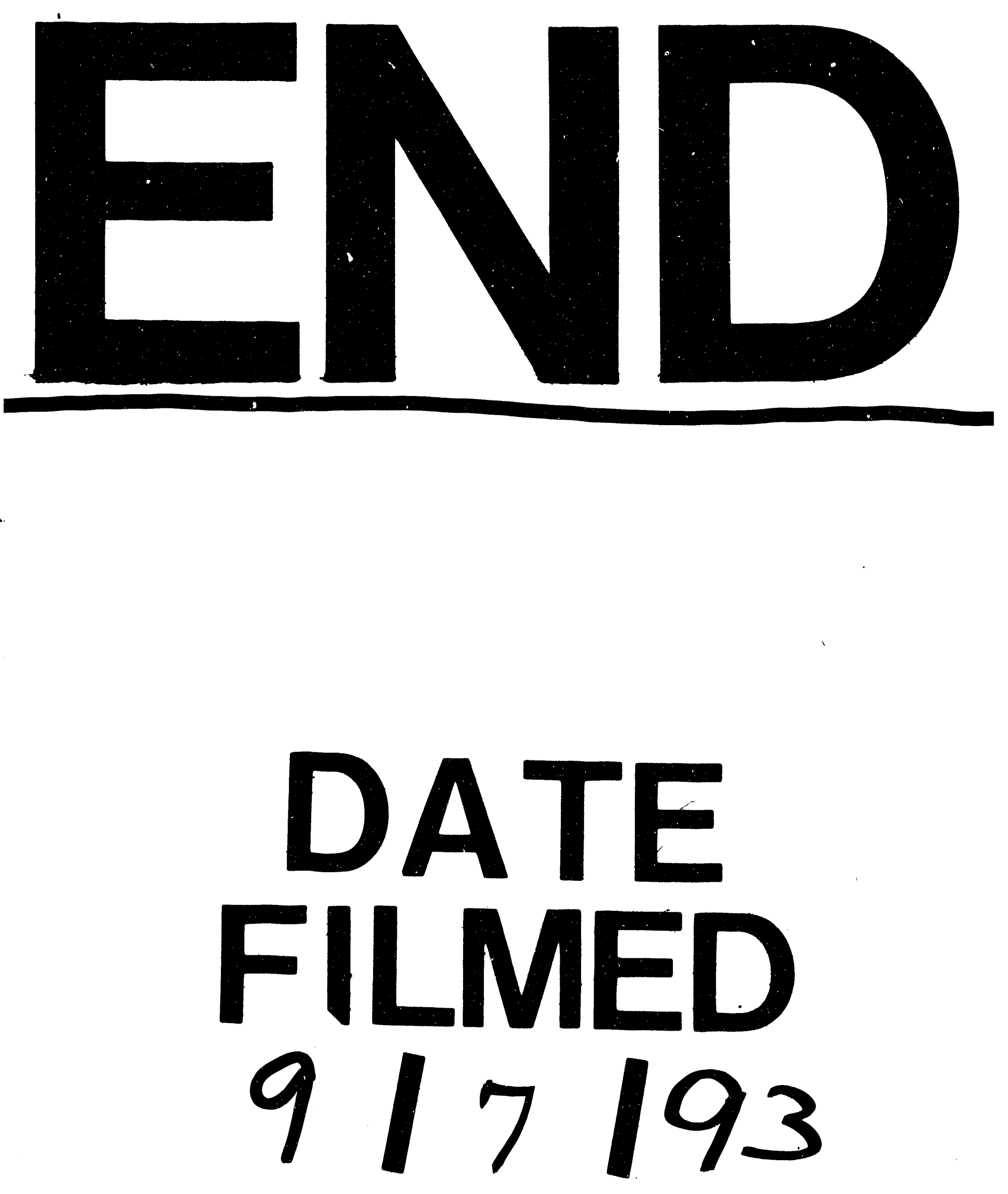


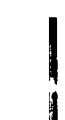

